\title{
Analysis of the Relationship between the Surface Hardness and Wear Resistance of Indirect Composites Used as Veneer Materials
}

\author{
Adriana Cláudia Lapria FARIA \\ Ubiratan Menezes BENASSI \\ Renata Cristina Silveira RODRIGUES \\ Ricardo Faria RIBEIRO \\ Maria da Gloria Chiarello de MATTOS \\ Department of Dental Materials and Prosthodontics, School of Dentistry of Ribeirão Preto, \\ University of São Paulo, Ribeirão Preto, SP, Brazil
}

\begin{abstract}
This study evaluated the surface hardness and wear resistance of indirect composites (Artglass and Solidex) and the existence of a correlation between these properties. Twenty-four specimens (12 per material) were fabricated using a polytetrafluoroethylene matrix (5.0 mm in diameter; $7.0 \mathrm{~mm}$ high) following an incremental technique. Polymerization was done with a xenon stroboscopic light curing unit. After polishing, the specimens were stored in water at $37^{\circ} \mathrm{C}$ during either 1 day $(\mathrm{n}=6$ per material) or 55 days ( $\mathrm{n}=6$ per material), after which Vickers surface hardness and wear resistance were assessed. Data were analyzed statistically by unpaired Student t-test, two-way ANOVA and Tukey's test. Surface hardness. Artglass had higher surface hardness than Solidex after 1-day immersion period ( $<<0.01)$, but after 55 days there was no significant difference between the materials $(\mathrm{p}>0.05)$. Comparing the materials at both periods, Artglass means differed significantly to each other $(\mathrm{p}<0.01)$, while no significant difference was found between Solidex means ( $\mathrm{p}>0.05)$. Wear resistance. Solidex had higher wear than Artglass after 1-day immersion period $(p<0.01)$, but no significant difference was found between the materials after 55 days ( $>>0.05$ ). Comparing the materials at both periods, Artglass means differed significantly to each other $(\mathrm{p}<0.01$ ), with higher wear at 55-day period, but no difference was found between Solidex means ( $>0.05)$. These results suggest that Artglass was better than Solidex in terms of hardness and wear resistance after 1-day water immersion. However, it was more susceptible to degradation, showing greater wear after 55 days. In conclusion, there was an inverse correlation between surface hardness and wear resistance for both Artglass and Solidex indirect composites, that is the higher the hardness, the lower the wear.
\end{abstract}

Key Words: surface hardness, wear resistance, indirect composite.

\section{INTRODUCTION}

The increasing demand of the patients for esthetic restorations to replace lost dental tissues has pushed the market to develop materials that fulfill this need.

The first generation of esthetic materials had unsatisfactory mechanical properties, which frequently led to loss of vertical dimension and extrusion of the opposing natural teeth (1). Several studies were performed in order to improve the surface hardness and wear resistance of composite restorative materials. The addition of quartz, barium glass and silica, among other materials, to the inorganic phase of the resin matrix increased its wear resistance by reducing the particle size and increasing the filler volume (2).

The properties of composites may be influenced by the type, size and volume of the filler particles as well as the union of the filler/matrix interface (3). The greater the content and size of particles, the higher the composite's wear resistance. However, the wear rate increases when the maximum size of filler particle is close to the size of the abrasive particles (4). The incorporation of $2-\mu \mathrm{m}$ filler particles reduces resin wear resistance compared to unfilled resins, while the incorporation of

Correspondence: Profa. Dra. Maria da Gloria C. de Mattos, Departamento de Materiais Dentários e Prótese, Faculdade de Odontologia de Ribeirão Preto, USP, Avenida do Café, S/N, Monte Alegre, 14040-904 Ribeirão Preto, SP, Brasil. Tel: +55-16-3602-4005. Fax: +55-163633-0999. e-mail: gloria@forp.usp.br 
$15-\mu \mathrm{m}$ filler particles increases the wear resistance of resins (5). Composite wear has been extensively investigated and it has been shown that resins with large-sized filler particles (conventional) and those with high filler content (hybrid) have better resistance to wear (6).

Although the incorporation of small-sized round filler particles to the organic matrix has been shown to increase composite resistance to wear, a previous study (7) found no significant difference between specimens with the same filler size and different shapes. A direct correlation between addition of silica and barium glass particles to the composite Bis-GMA/TEGDMA matrix and the improvement of surface hardness has been demonstrated (8). Hardness is higher in microparticle composites than in hybrid composites $(7,9)$.

The type and size of filler particles influence water sorption, and barium glass has higher water sorption than quartz. This indicates that, in an aqueous medium, resins containing barium glass might have their surface altered, which will interfere with their hardness. It is suggested that water sorption takes place at filler/ composite matrix union (10). Although water has a degrading action on resin surface, this action is limited. However, other solvents present in the oral cavity may yield a different behavior of the same properties (11).

Although some reports claim that there is no correlation between wear resistance and composite hardness (12), other studies state that there is, in fact, a direct correlation between these properties $(13,14)$. This study evaluated surface hardness and wear resistance of two indirect composites of different compositions, and the existence of a correlation between these properties. In addition, the effect of water immersion on hardness and wear resistance was assessed.

\section{MATERIAL AND METHODS}

The tested materials were 2 commercial brands of indirect composite resins commonly used for fabrication of veneers and inlays/onlays: a microparticle composite (Artglass; Heraeus Kulzer, Germany) and a hybrid composite (Solidex; Shofu Inc., Kyoto, Japan). Artglass is composed of a multifunctional methacrylic acid ester (30\% by weight) associated to silicon dioxide filler and barium-aluminum-silicate glass $(70 \%$ by weight), silanized, and inorganic pigments. Solidex has BIS-GMA as its composite matrix (22\% by weight), associated to inorganic ceramic micro-fillers (silicon dioxide and aluminum dioxide particles - $53 \%$ by weight) and co-polymers with multifunctional resin ( $25 \%$ by weight).

Twenty-four specimens (12 per material) were fabricated using a polytetrafluoroethylene matrix (5.0 $\mathrm{mm}$ in diameter; $7.0 \mathrm{~mm}$ high) following an incremental technique, according to which the matrix was filled with 4 composite increments, each polymerized for $90 \mathrm{~s}$ with a xenon stroboscopic light curing unit (UniXS; Heraeus Kulzer GmbH, Wehrheim, Germany) with a polymerization rate between $320-520 \mathrm{~nm}$. Thereafter, the specimen was removed from the matrix and submitted to an additional 180 -s polymerization cycle to eliminate any curing flaws due to matrix interference.

The specimens were individually fixed on a square-shaped Plexiglass plate $(2.0 \mathrm{~cm}$ x $2.0 \mathrm{~cm}$ x 4.5 $\mathrm{mm}$ ) with a drop of a quick-setting cyanoacrylate ester adhesive (Super Bonder ${ }^{\circledR}$ Instant Adhesive; Loctite do Brasil Ltda, Itapevi, SP, Brazil). Self-curing acrylic resin was placed around the specimen to increase fixation. The specimens were polished with wet 320-, 400-, 600and 1200-grit sandpapers in a polishing machine to obtain a plane, smooth and glossy surface, facilitate light reflection on hardness test and ensure indentation reading. The polished specimens were immersed in light-proof recipients containing saline and stored in a stove at $37^{\circ}$ $\pm 1^{\circ} \mathrm{C}$ during either $24 \mathrm{~h}$ ( 1 day; 6 specimens per material) or $1320 \mathrm{~h}$ (55 days; 6 specimens per material).

Surface hardness test. After the storage periods, Vickers surface hardness test was performed using a digital microhardness tester (Shimadzu HMV-2, Shimadzu HMV-2, Tokyo, Japan). Three indentations per specimen were made with a load of $0.5 \mathrm{~N}$ and a loading time of $40 \mathrm{~s}$, and the diagonals were measured with a 40X magnifying lens.

Wear resistance test. The wear resistance test was performed in an apparatus developed at the Department of Dental Materials and Prosthodontics of the School of Dentistry of Ribeirão Preto (USP) by Dr. Ruy Barbosa Roselino and Dr. Roberto Ferreira Roselino (Figs. 1A-1C). Briefly, the Plexiglass plate containing the specimen was positioned at the bottom end of the metallic cylinder (C). A metal plate was initially positioned at the base of the apparatus (B) to perform the first measurement $(\mu \mathrm{m})$, which was recorded by a digital caliper kept in contact with a upper end of the of the metallic cylinder where the specimen was positioned. A $1 \mathrm{~kg}$ load was used. Thereafter, the load was 
released and the metal plate was replaced by a Plexiglass plate with a 1000-grit sandpaper strip fixed to its surface with double-face adhesive tape. The specimen was positioned in contact with the sandpaper strip under a 50 g load and the apparatus was switched on (Fig. 2). A 12 $\mathrm{V}$ engine moved the base to which the Plexiglass/ sandpaper set was attached, thus performing a dry wear of specimen surface (A) at $70 \mathrm{~mm} / \mathrm{min}$ speed. Four cycles were done, being each at an unused area of the sandpaper strip, and the equipment was switched off.

Next, a second measurement $(\mu \mathrm{m})$ was performed. The Plexiglass plate/sandpaper set was changed by the metal plate and $1 \mathrm{~kg}$ load initially used. The difference between the first and second measurements $(\mu \mathrm{m})$ determined the wear of each specimen test. Throughout the test, the specimens that were not being used were kept in light-proof recipients containing saline and stored in a stove at $37^{\circ} \pm 1^{\circ} \mathrm{C}$.

Vickers hardness and wear resistance data were analyzed statistically by the unpaired Student's t-test to compare periods and materials, as well as two-way analysis of variance (ANOVA) and Tukey's post-hoc test. The results were presented as means \pm standard deviation. Significance level was set at 5\%.

\section{RESULTS}

Surface Hardness Test. Vickers hardness means $( \pm \mathrm{SD})$ of both materials for the 2 storage periods are given on Table 1 . The analysis of the interactions



Figure 1. Wear test apparatus. between materials and storage periods by analysis of variance showed that the highest Vickers hardness means was found for Artglass in the 1-day period $(p<0.01)$. In the 55-day period, the Vickers hardness means of the materials did not differ significantly to each other and both were statistically similar to that of Solidex in the 1-day period $(\mathrm{p}>0.05)$.

Wear Resistance. Composite wear means ( $\pm \mathrm{SD}$ ) of both materials for the 2 storage periods are given on Table 2. The wear of Solidex in both storage periods did not differ significantly to that of Artglass in the 55-day period ( $>00.05$ ). Artglass in the 1-day period had the lowest wear means $(\mathrm{p}<0.05)$. The interaction of periods and materials as analyzed by two-way ANOVA did not show statistically significant difference ( $>0.05$ ). Thus, time was a significant factor in wear resistance for Artglass composite, which was not observed for Solidex.

Correlation Tests. To assess a possible correlation between surface hardness and wear resistance, regression and correlation tests were done, confronting surface hardness means of each specimen (Vickers hardness, abscissa axis) against the corresponding wear means (in $\mu \mathrm{m}$, ordinate axis). The $r$ value (0.6208 ) indicates a correlation and an inverse relation between them and Student's t-test confirmed the correlation between the confronted factors $(\mathrm{p}<0.05)$. Hence, there was an inverse linear correlation between hard-

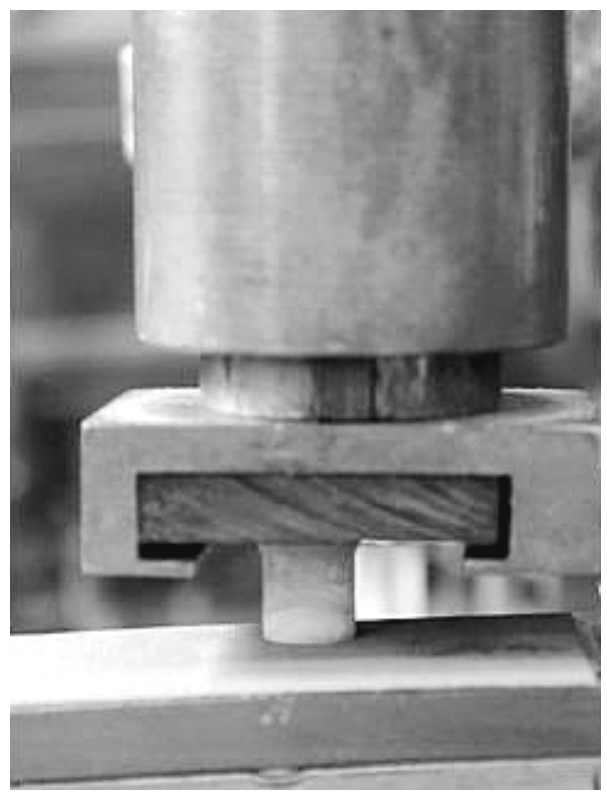

Figure 2. Detail of the wear resistance test. 
ness and susceptibility to wear for the storage periods ( 1 and 55 days) and materials (Artglass and Solidex). Figure 3 illustrates this correlation and data dispersion.

Table 1. Vickers hardness of the indirect composites used as veneer materials.

\begin{tabular}{lcc}
\hline Material & \multicolumn{2}{c}{ Water immersion time } \\
\cline { 2 - 3 } & \multicolumn{1}{c}{1 day } & 55 days \\
\hline Artglass & $19.08 \pm 1.77 \mathrm{Aa}$ & $15.42 \pm 0.97 \mathrm{Bb}$ \\
Solidex & $15.33 \pm 1.25 \mathrm{Bb}$ & $14.00 \pm 0.83 \mathrm{Bb}$
\end{tabular}

Different uppercase and lowercase letters indicate statistically significant difference in lines and columns, respectively.

Table 2. Wear of the tested indirect composites $(\mu \mathrm{m})$ after wear resistance assays.

\begin{tabular}{lcc}
\hline Material & \multicolumn{2}{c}{ Water immersion time } \\
\cline { 2 - 3 } & \multicolumn{1}{c}{1 day } & 55 days \\
\hline Artglass & $22.33 \pm 15.78 \mathrm{Bb}$ & $45.66 \pm 19.05 \mathrm{Aa}$ \\
Solidex & $41.00 \pm 15.85 \mathrm{Aa}$ & $38.16 \pm 10.42 \mathrm{Aa}$ \\
\hline
\end{tabular}

Different uppercase and lowercase letters indicate statistically significant difference in lines and columns, respectively.

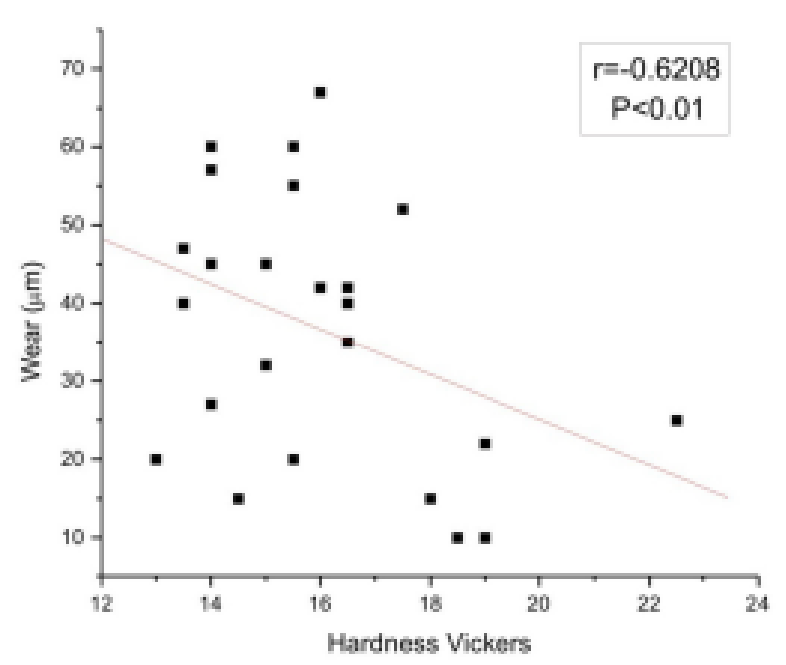

Figure 3. Scatterplot of wear and Vickers hardness. Significant correlation was observed $(r=-0.6208 ; \mathrm{p}<0.01)$.

\section{DISCUSSION}

The difference in wear and Vickers hardness means suggests that the difference of chemical composition and filler content as well as the characteristics of each material interfere with the composite's properties. Similar results have been reported by Suzuki et al. (7), who found higher wear resistance when small-sized round particles were associated to the matrix, and by Braen et al. (8) and Chung and Greener (14), who observed higher surface hardness when the filler content was also higher. Thus, Artglass, which has $70 \%$ by weight of microfiller particles in its composition, had greater Vickers hardness than Solidex, which is a hybrid composite with $53 \%$ by weight of inorganic microfiller particles, as previously reported $(7,9)$.

The findings of the present study showed a direct inverse linear correlation between surface hardness and wear resistance, which justifies the analysis of these properties conjunctly. Hence, the material's wear decreases as its surface hardness increases, which is consistent with the outcomes of Mandikos et al. (15). However, these authors (15) recommend care while interpreting their results, given that some materials may not behave in the same way. Peutzfeldt et al. (16) evaluated several dental materials, including Z100 composite resin, and also found an inverse correlation between Rockwell hardness and wear. Such correlation was observed for both indirect composites used in the present study. Care must be taken on extrapolating these results due to the high dispersion observed (Fig. 3).

The storage time of the composites in water interfered with their properties. The decrease of hardness and wear resistance of the tested composites, especially Artglass, might be justified based on the reports of Sölderholm et al. (17), according to whom the permeability of resins and their hydrolytic degradation interfere with their wear, and Tarumi et al. (10), who found that barium is reactive when immersed in water and, when eliminated, interferes with resin mechanical properties. Such reports justify the good wear resistance of Artglass after 1-day immersion and the high wear rate after 55 days, considering that this composite has barium glass silicate in its composition. It has been demonstrated that the chemistry of the filler particles play an important role on the wear resistance of composites only when there are significant changes on the chemical composition and on the filler particle 
content because slight changes do not affect the behavior of these materials in terms of wear (18). Furthermore, Freund and Munksgaard (19) have found that there is a hydrolytic action of the esterase enzyme on the degradation of resin restorations in oral environment.

According to the methodology proposed and based on the obtained results, the following conclusions may be drawn: 1. Although Artglass initially had a higher surface hardness, as the immersion period increased, surface hardness decreased significantly; 2. Artglass wear was higher at 55-day storage period, which confirmed the influence of the immersion time. On the other hand, there was no significance difference for Solidex, which seemed to be only slightly influenced by the immersion time; 3 . There was an inverse correlation between surface hardness and wear resistance for both Artglass and Solidex indirect composites, that is the higher the surface hardness, the lower the wear.

\section{RESUMO}

Este trabalho avaliou a dureza superficial e resistência à abrasão de duas resinas compostas indiretas (Artglass e Solidex) bem como a existência de correlação entre estas propriedades. Foram confeccionados 24 corpos-de-prova (12 de cada compósito) pela técnica incremental utilizando uma matriz de politetrafluoretileno. A polimerização foi feita usando uma unidade fotopolimerizadora com lâmpada estroboscópica de xenônio. Após polimento, os corpos-de-prova foram armazenados em água a $37^{\circ} \mathrm{C}$ durante períodos de 1 dia ( $\mathrm{n}=6$ por material) ou 55 dias ( $\mathrm{n}=6$ por material), após os quais a dureza superficial Vickers e a resistência à abrasão foram testadas. Os dados foram analisados estatisticamente por meio do teste $t$ de Student não-pareado, ANOVA a dois critérios de classificação e teste de Tukey. A comparação entre os materiais para a dureza superficial demonstrou que, no período de 1 dia, Artglass teve maior dureza $(\mathrm{p}<0,01)$. No período de 55 dias não houve diferença estatisticamente significante entre os materiais $(p>0,05)$. Comparando os materiais nos dois períodos, Artglass apresentou diferença estatisticamente significante $(\mathrm{p}<0,01)$, o que não foi observado para o Solidex $(\mathrm{p}>0,05)$. A comparação entre os materiais para a resistência à abrasão demonstrou que, no período de 1 dia, o Solidex teve maior desgaste $(\mathrm{p}<0,01)$ que o Artglass, enquanto no período de 55 dias não houve diferença significante ( $>0,05)$. Comparando os materiais em ambos os períodos, houve diferença estatisticamente significante para o Artglass $(\mathrm{p}<0,01)$, com maior desgaste no período de 55 dias, mas não houve diferença significante para o Solidex $(p>0,05)$. Esses resultados sugerem que o Artglass teve melhor desempenho que o Solidex quanto à dureza e resistência ao desgaste após 1 dia de imersão em água; porém, foi mais suscetível à degradação, com maior desgaste após 55 dias. Concluiu-se que houve correlação inversa entre dureza superficial e resistência ao desgaste para os compósitos estudados (Artglass e Solidex), ou seja, quanto maior a dureza superficial, menor o desgaste.

\section{REFERENCES}

1. Blixt M, Coli P. The influence of lining techniques on the marginal seal of class II composite restorations. Quintessence Int 1993;24:203-210.

2. Leinfelder KF. Using composite resin as a posterior restorative material. J Amer Dent Assoc 1991;122:65-70.

3. Condon JR, Ferracane JL. Evaluation of composite wear with a new multi-mode oral wear simulator. Dent Mater 1996;12:218-226.

4. Draughn RA, Harrison A. A relationship between abrasive wear and microstructure of composite resins. J Prosthet Dent 1978;40:220-224.

5. Li Y, Swartz ML, Philips RW, Moore BK, Roberts TA. Effect of filler content and size on properties of composites. J Dent Res 1985;64:1396-1401.

6. McLundie AC, Patterson CJW. Comparison of the abrasive wear in vitro of a number of composite resin. Br Dent $\mathrm{J}$ 1982;153:404-406.

7. Suzuki S, Leinfelder KF, Kawai K, Tsuchitani Y. Effect of particle variation on wear rates of posterior composites. Amer J Dent 1995;8:173-178.

8. Braen M. Mechanical properties and filler fraction of dental composites. Dent Mater 1989;6:346-349.

9. Willems G, Lambrechts P, Braem M, Celis JP, Vanherle G. A classification of dental composites according to their morphological and mechanical characteristics. Dent Mater 1992;8:310-319.

10. Tarumi H, Torii M, Tsuchitani Y. Relationship between particle barium glass filler and water sorption of light-cured composite resin. Dent Mater 1995;14:37-44.

11. Ferracane JL, Berge HX, Condon JR. In vitro aging of dental composites in water - Effect of degree of conversion, filler volume and filler/matrix coupling. International $\mathrm{J}$ Biomed Mater Res 1998;42:465-472.

12. Lappalainen R, Yli-Urpo A, Seppa L. Wear of dental restorative and prosthetic materials in vitro. Dent Mater 1989;5:35-37.

13. Kawai K, Iwami Y, Ebisu S. Effect of resin monomer composition on toothbrush wear resistance. J Oral Rehabil 1998;25:264-268.

14. Chung KH, Greener EH. Correlation between the degree convertion, filler concentration and mechanical properties of posterior composite resins. J Oral Rehabil 1990;17:487-494.

15. Mandikos MN, McGivney GP, Davis E, Bush PJ, Carter JM. A comparison of the wear resistance and hardness of indirect composite resins. J Prosthet Dent 2001;85:386-395.

16. Peutzfeldt A, Garcia-Godoy F, Asmussen E. Surface hardness and wear of glass ionomers and compomers. Amer J Dent 1997;10:15-17.

17. Sölderholm KJ, Zigan M, Ragan M, Fischlschweiger W, Bergman M. Hydrolytic degradation of dental composites. J Dent Res 1984;63:1248-1254.

18. Nagarajan VS, Jahanmir S, Thompson VP. In vitro contact wear of dental composites. Dent Mater 2004;20:63-71.

19. Freund M, Munksgaard EC. Enzymatic degradation of BisGMA/TEGDMA-polymers causing decreased microhardness and greater wear in vitro. Scand J Dent Res 1990;98:351-355.

Accepted April 29, 2006 